\title{
Visual Materials, Staging, and the Internet in Literature Classrooms
}

\author{
Edebiyat Ö̆̆retiminde Görsel Araçlar, Sahneleme ve İnternet
}

\begin{abstract}
Arda ARIKAN*
Abstract: The aim of this paper is to show, through applicable activities; how the use of visuals can alter the way we teach literature in English as a foreign language classrooms. I designed a syllabus for the course titled "Introduction to British Literature I and II" in which visual materials were used to teach some major literary terms and movements. Two main data sources; the instructor's memos and prospective teachers' opinions of these activities were collected for this research study. Fashioned so as to build a more interactive literature classroom, the syllabus was realized with second year pre-service 22 ELT teachers and the findings suggest that using visual materials in literature classrooms can energize and motivate prospective teachers, energize the classroom interaction, bring greater motivation, and nurture students' need to concretize some of the abstract notions they studied. In this paper, descriptions of the tasks are given followed by the opinions of the students on these activities.
\end{abstract}

Keywords: Literature, English literature, activity, visual, Victorian Age, story, Internet

Öz: Bu çalışmanın amacı yabanıı dil olarak İngilizce öğretilen sınıflarda edebi metinlerin özellikle uygulamalı etkinlikler yoluyla kullanılmasının öğretim süreçlerine etkisini ele almaktır. Bu uygulamalı araştırmada edebi terim ve akımların öğretilmesi için görsel araçların yoğunlukla kullanıldığı bir izlence tasarlanmıştır. Çalışmada "İngiliz Edebiyatına Giriş I ve II" derslerini yürütmekte olan öğretim üyesinin (araştırmac1) gözlem notları ve öğretmen adaylarının görüşleri veri olarak kullanılmıştır. Sınıf içi iletişim ve etkileşimi önceleyen bu çalışmaya 2. Sınıfta öğrenim gören toplam 22 İngilizce öğretmeni adayı katılmıştır. Çalışmanın sonuçları görsel araçların temel alındığı etkinliklerin sınıf içi etkileşim ve iletişimi artırdığı, öğretmen adaylarını motive ettiği ve somutlaştırılması oldukça zor olan soyut terimlerin anlaşılmasını kolaylaştırdığını göstermiştir. Bu çalışmada önce etkinlikler betimlenmiş, daha sonra da öğretmen adaylarının öğrenim süreçleri hakkındaki görüşleri paylaşılmıştır.

Anahtar sözcükler: Edebiyat, İngiliz edebiyatı, etkinlik, görsel, Viktorya Dönemi, öykü, İnternet

\section{Introduction}

English is taught in cooperation with literature teaching programs in which EFL students read many literary works to develop their language skills (Buckledee, 2002). Although approaches to teaching literature in second and foreign language classrooms have been discussed from a theoretical perspective, more information is needed about the actual classroom applications in order to determine whether adjustments are needed to the way literature is taught. In this respect, while research has shown that using visual materials in education improves learning (Stokes, 2005), very few studies have reported on the use of visuals in literature classrooms. To address this gap in the literature, this article describes a classroom procedure involving the

\footnotetext{
* Assoc. Prof. Dr., Akdeniz University, Faculty of Letters, Department of Western Languages and Literatures, Division of English Language and Literature, Antalya, ardaari@gmail.com
} 
teaching of literature through the use of visual materials as primary texts.

Research shows that using visual materials in education improves learning at all levels of instruction (Açıkgöz, 2003). This application-based study took place at a faculty of education where pre-service English language teachers were enrolled in a literature course. The principal aim of the study was to create a more active and interactive literature classroom, using visual materials in order to make literature teaching more effective. With this in mind, I re-designed a segment of a second-year course I had been teaching over 6 semesters, entitled "Introduction to British Literature" in which literary terms and movements were taught, as a two semester course, to facilitate students' understanding of upcoming literature courses such as drama, the novel, poetry, and the short story. The primary materials used in our course consisted of visual materials, mainly photographs and videos and the activities aimed to foster interaction in the classroom through creating discussions and student work in which students came up with their own ideas rather than passively reading information about literature or listening to the instructor's lectures. Previous research showed that literature teaching supported by visual materials increases success and helps creating a positive classroom atmosphere (Arikan, 2008a; Arikan, 2009). Hence, these activities are thought to be helpful in contexts where second or foreign language learners study literature by:

1. providing appropriate texts and contexts in the teaching of literature;

2. employing technology in literature classrooms;

3. helping students acquire literary knowledge in a more robust manner;

4. developing students' language skills;

5. making use of multiple intelligences including visual and kinesthetic learners whose development is rarely considered in traditional literature classrooms.

\section{Methods}

In this study, the leading question concerned whether activities based on visual materials could have a positive effect on students' learning of literary terms and movements. The effects of using visual materials as primary texts on students' learning of literary ages, movements, and terms was evaluated through feedback sheets obtained from the prospective teachers of English; in addition, the researcher reviewed the video recordings of each session, focusing on the nature and quality of the student interactions. In this article, the activities used will first be described; then, an analysis and evaluation of the outcomes of students' performances will be shared, followed by a discussion of the whole process. It should be noted that throughout the instructional process, Smaldino and others' (2005) ideas on instructional materials were used to connect technology and teaching from a theoretical perspective.

\section{Procedures}

\section{Activity 1. The Middle Ages on Video}

\section{Aim: Learning about the Middle Ages}

Prospective teachers of English have always enjoyed compelling films on the Middle Ages in my classrooms. They were particularly interested in The Name of the Rose which has increased their interest in the Middle Ages. In this activity, students watched some excerpts from the movie silently and discussed those scenes to see what life would have been like back then. Following these discussions, and by using these visual images as a springboard for further activities, they decided on a list of qualities of the Middle Ages and read their coursebook to 
compare and contrast the knowledge they aquired from the film and such book-based information. After this stage, some other films were watched, this time by focusing on Britain in the Middle Ages.

\section{Activity 2. Victorian Photographs}

\section{Aim: Family Make up and Social Relationships in the Victorian Age}

Kartal and Arikan $(2010,93)$ point out that "it has become necessary to teach literature in a virtual environment, or, at least, to make a connection with that environment". Visual materials representing literary movements and ages are good resources through which we can motivate our students and leave vivid impressions of the age in their minds. In this activity, students search for photographs found in various web sites by focusing on the nature of the societal form in that era. As prospective teachers studied these visual materials, they brainstormed their ideas and feelings about the photographs they collected, so as to form an understanding of cultural and social life in that era.

Various forms of activities were possible with these materials such as script or dialogue writing, dramatizing, or acting. In our case, prospective teachers of English wrote dialogues by using through employing the visual materials they collected as though they were living in those specific eras. Prospective teachers of English introduced their imaginary families to their classmates, wrote letters to each other, and kept a diary to tell about their lives and social environment in detail. Students, then, compared their texts with the encyclopedic information and literary texts so as to compare and contrast various pieces of information about which they wrote and the knowledge they attained from such encyclopedic information. In short, prospective teachers exploited these photographs extensively by studying them in a detailed manner and compared what they thought and felt with written texts.

\section{Activity 3. Making Art Work: Collages}

\section{Aim: Learning literary terms metaphor, simile, etc.}

Teaching figurative language has always been the most compelling as well as most tiring part of literature teaching for of two main reasons. First, literature instructors must teach the literary terms with accurate and comprehensible examples. Second, they must ask learners to apply these terms while reading some literary texts.

In this activity, students were given abstract concepts such as "love" or "loss" and they were asked to cut and glue pictures from magazines to bring together their pictorial and visual definition of these concepts. Then, they were asked to talk in groups to identify what these pictures brought to their minds in relation to the literary terms they studied. Finally, students worked with the literary terms as they appeared in written materials and reformulated their collages by adding scripts onto them.

One student, for instance, glued a picture of a big "horse" under which he cut and glued the words "powerful" and "as" suggesting "as strong as a horse". Showing this to her classmates, they easily figured the relationship out and exclaimed "that's easy: as strong as a horse. That's a simile". After this preliminary stage, students prepared collages of the figurative language they found astonishing in the texts read. One student, for instance, presented a matching activity of "metaphors and drawings" in which he gave pieces of the metaphorical texts and numerous pictures and collaborated to match the texts with the drawings. Students then wrote their own metaphors and transformed them into collages. 


\section{Activity 4. Re-ordering Pictures}

\section{Aim: Understanding the (Plot) Structure (Freytag's Triangle)}

Literature students often have difficulty in identifying the plot structure in a given text. The importance of the conflict in a plot structure is obvious and in this activity students were asked to re-order a series of pictures to make a meaningful and effective story line. As groups of students wrote their stories in cooperation with their peers by using re-ordered pictures, they also pointed out the parts that made the whole: exposition, conflict, rising action, climax, falling action and resolution. After completing their stories, they were asked to re-arrange the plot structure by exchanging the climax with another picture so that the whole plot (and thereby meaning and effect) was changed. The students then discussed how plot structure works in making meaning and creating effect. As a follow-up activity, the students were asked to bring in their own sets of pictures and present the related story line, after which their peers were asked to change the climactic order to complete the cycle. Through this activity, students were able to learn more about the importance of the narrative voice by understanding that the way an author orders events has an effect on the meaning and overall effect in a literary work.

\section{Activity 5. The importance of the setting}

\section{Aim: Understanding the effect of the setting on literary meaning making}

Apart from giving symbolic meanings to particular settings, authors and playwrights "often use setting as one of the means of organizing their stories" (Roberts, 2006, 111). The impact of setting on literary meaning and its effect on the reader is obvious. However, students often complain that they do not understand the meaning of particular literary texts or stage acting.

In order to familiarize students with using the context clues grounded in the setting of a literary text, the final dialogue in Bernard Shaw's play Candida was studied. Before reading the whole play, the students read the dialogue, and then they were invited to answer two questions: who the characters were and what the main problem could be. The students worked in groups to decide what the dialog was about without having been given information on the setting. Then, a photograph of a classroom was shown in order to help them to understand that the dialogue took place in a classroom. The students were then asked to answer the two questions again, and their answers were collected. Finally, a fancy, baroque-style room was shown, and the cycle was repeated. The students' interpretations of the dialog and the characters' identities changed each time the setting changed. Afterward, the students reported their fascination with how particular settings changed the meaning they gave to literary texts; as the settings changed, so did the meanings of the words and the identities of the characters. Their interpretations moved from romantic love to betrayal as the students first associated the characters' dialogue with a platonic teacher-student love affair, and later with a serious betrayal in a marriage.

\section{Activity 6. On-stage Acting}

\section{Aim: Studying stage types}

The importance of the relationship between literary terms related to the physical stage and staging techniques described in plays is obvious. However, stage types, props, acting and the effects of these elements on the audience have been difficult concepts for many students. Although, as Özmen (2011) demonstrated acting has positive effect on the development of prospective teachers of English, very few students have had the opportunity to watch a performance on any of these stage types, and even fewer have actually acted on stage. 
Hence, in this activity, we decided to identify the most suitable stage type for a miniproduction of the opening scene of Shakespeare's Macbeth. We used the largest space availablea computer laboratory, since the tables and chairs were easy to move- and studied the available stage types found in the literature. We then drew outlines of these stage types with chalk, including properties such as audience seating, and then performed the opening scene, with tables serving as a thrust stage, proscenium arch stage, and arena type stage. The prospective teachers prepared the stages in groups and acted the scene, while the rest of the class watched the performance. All students were then asked to focus on how each stage type affected them, both as actors and as the audience. Following their dramatic action, the prospective teachers discussed the effects of these stage types from the viewpoint of actors, audience, and playwrights. By taking on the role of the playwright, the prospective teachers imagined why that particular stage type might have been chosen as the most appropriate for a specific performance. The prospective teachers had mixed opinions on the best stage type to perform the scene from Macbeth, but they generally expressed the opinion that either the thrust stage or an arena type stage would be the most effective.

\section{Findings and Discussion}

My notes on the classroom meetings have shown that prospective teachers were never bored in these activities and that classroom interaction increased dramatically. Our classroom interaction showed that students were actively involved and these activities energized the classroom. Rather than reading and listening as was the case in the previous class meetings, they were working hard in a positive atmosphere and with fascinating media while learning about literature. However, during the instructional process, prospective teachers actively created materials or proposed their ideas and experiences some of which were negative. Prospective teachers' reports inspired the researcher (syllabus designer) to make changes in his future curriculum planning. Despite some minor negative opinions, this process showed the energizing power of visuals, acting, and the Internet in the teaching of literature.

\section{Prospective Teachers' Opinions}

\section{Positive Sides of the Application}

Prospective teachers claimed that they would rather be instructed with these kinds of activities in the future except for one who claimed that even though it was a "fascinating experience, [s/he] would rather read rather than act on stage". Below are some of the exemplary opinions of the participants:

- 'I enjoyed the activities while learning something about literature, so I will most probably never forget what I have learned'.

- 'That was nice to see my silent friends express themselves. These activities caused us to interact more'.

- 'This activity, of course, was better because I also participated in the presentations'.

- 'This activity helps us gain some knowledge about the painting before we actually get into the topic of study'.

- 'In this activity students are alert, they are in the center'.

- 'I felt as if we were on the theater stage'.

- 'I have been teaching literature for over ten years but have never been shown a photograph or painting in these courses. Though it had never occurred to me that we could teach literature with them. These materials make this course look like an illuminated funfair'. 


\section{Negative Sides of the Application}

Some negative ideas were collected from the prospective teachers who participated in these activities:

- 'This activity should come after the explanation because although we can infer the explanation from the example, explanations are necessary'.

- 'I think not all topics can be taught with these activities'.

- 'It is not detailed, so all of the subtopics may not be taught'.

- 'Some students may not be good at creative things such as acting. They, because of their inability, can’t enjoy these activities'.

\section{Prospective Teachers' Suggestions}

Participants suggested the following so as to improve the syllabus:

- 'More visual materials are needed'.

- 'I need to be given more time for the activities'.

- 'More texts should be assigned and studied because we need to have more information apart from what these activities make us learn'.

\section{Conclusion}

Using visual materials to promote student interaction while teaching and learning literature is a much more complex activity than it might at first appear, but in our context, such activities pulled students into a colorful and illuminating space. I believe that with some adaptation to the implementation process, such activities can be successfully used in many contexts where the aims of literature go beyond rudimentary reading for comprehension. Today, blogs, forums, games, music and video files, software, and web sites, are all accepted as educational tools that can be used in the teaching of foreign languages (Arıkan, 2008b), and such media may be used in literature courses for many purposes. It should also be noted that many other films are ready to be used including, but not limited to various ages of British history such as those on Henry VIII, Queen Elizabeth, Queen Victoria, WW I and WW II, among many others.

As this whole process of preparing, using, and evaluating visual materials for the teaching of literature has shown, interested teachers should take the following issues into consideration:

- The process of preparing such activities requires greater time and energy, but as such materials flourish, planners will gain control of the whole process.

- Often, connecting pieces of visual materials with the syllabus through brainstorming and reflecting is the best thing to do in spite of the scarcity of activities and materials available on the market.

- Because acting requires many artistic and technical skills, both course instructors as well as students should be involved in learning more about the theory and practice of acting.

This study was an application-based study which was a small-scale attempt to incorporate various forms of on-line and real world tools and activities into the teaching of literature. However, I believe that this research study will help practitioners:

1. to see ways of connecting various forms of literary topics and terms with appropriate visual materials.

2. to understand the value of technology in the contemporary literature classroom.

3. to make use of their multiple intelligences while dealing with appropriate activities.

4. to view literary knowledge as linguistic events where the intersection of spoken, visual 
and written materials can contribute to foreign language learners' learning of literature through developing their language skills.

5. to show a helpful working sheet for teachers who will prepare and create similar materials.

It can be concluded that, as suggested by Stokes (2005), further research is needed to develop tools that measure the individuals' degrees of visual literacy, including skills of creating and interpreting visual language, so as to gain an in-depth understanding of using visuals in literature classrooms. Similarly, script writing and acting should be studied carefully in the future because of the fact that drama and acting include many activities and skills that can be used by prospective teachers of English in their future classrooms.

\section{REFERENCES}

Açıkgöz, K. Ü. (2003). Aktif Öğrenme. İzmir: Eğitim Dünyası Yayınları.

Arikan, A. (2008a). "Formalist (Linguistic) criticism in an English Language Teacher Education Program: The REWARD Approach”. Iranian Journal of Language Studies, 2 (4), 417-430.

Arikan, A. (2008b). "Using Internet Groups in the Learning of Literature". Hacettepe University Journal of Education, 34, 19-26.

Arikan, A. (2009). “Edebiyat Öğretiminde Görsel Araç Kullanımı: Kısa Öykü Öğrenimi”. Ondokuz Mayls Üniversitesi Eğitim Fakültesi Dergisi, 27, 1-16.

Buckledee, S. (2002). "Language and Literature in Tertiary Education: The case for stylistics". English Teaching Forum, 40 (2), 8-12.

Collie, J., \& Slater, S. (1987). Literature in the Language Classroom: A resource book of ideas and activities. Cambridge: Cambridge University Press.

Smaldino, S., E., Russell, J., D., Heinich, R., M., \& Molenda, M. (2005). "Instructional technology and media for learning" ( $8^{\text {th }}$ ed.). Upper Saddle River, NJ: Merrill Prentice Hall.

Kartal, E., \& Arikan, A. (2010). "A Recommendation for a New Internet-Based Environment for Studying Literature”. US-China Education Review, 7 (7), 93-99.

Özmen, K. S. (2011). “The Impact of an Acting Course on Prospective Teachers' Beliefs About Language Teaching”. Eurasian Journal of Educational Research, 45, 89-106.

Stokes, S. (2005). "Visual Literacy in Teaching and Learning: A Literature Perspective". Source http://ejite.isu.edu/Volume1No1/Stokes.html 
